\title{
Phytochemical Screening, Gas Chromatography-mass Spectrometry Analysis, and Antidiabetic Effects of Corchorus olitorius Leaves in Rats
}

\author{
Heba M. I. Abdallah ${ }^{1 *}$, Gehad A. Abdel Jaleel ${ }^{1}$, Hala Sh. Mohammed ${ }^{2}$, Sawsan S. Mahmoud ${ }^{1}$, Nemat A. Yassin ${ }^{1}$, \\ Amina A. Gamal el Din ${ }^{3}$, Nermeen M. Shaffie ${ }^{3}$, Fatma A. Bassyouni ${ }^{4}$ \\ ${ }^{1}$ Department of Pharmacology, Medical Research Division, National Research Centre (ID: 60014618), Giza, Egypt; ${ }^{2}$ Department \\ of Pharmacognosy, Faculty of Pharmacy (Girls), Al Azhar University, Cairo, Egypt; ${ }^{3}$ Department of Pathology, Medical Research \\ Division, National Research Centre (ID: 60014618), Giza, Egypt; ${ }^{4}$ Department of Chemistry of Natural and Microbial Products, \\ Pharmaceutical Research and Drug Industries Division, National Research Centre (ID: 60014618), Giza, Egypt
}

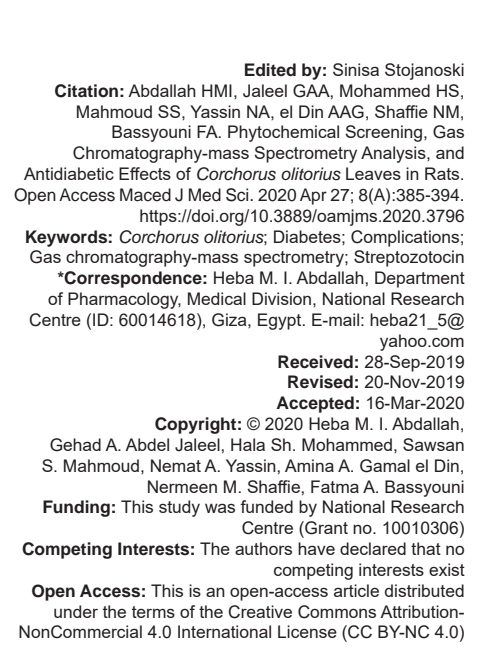

Abstract

BACKGROUND: Therapies for diabetes mellitus are still meeting failure in most cases, especially in the developed stages of the disease due to incredible associating complications. Hence, there is a need for continuous development of curative therapies for that stubborn disease.

AIM: We aimed to investigate the antidiabetic effects of one of the most popular plants cultivated in Egypt, C. olitorius. METHODS: Phytochemical screening of total alcoholic extract of Corchorus olitorius leaves and its aqueous and chloroform fractions revealed the presence of flavonoids, saponins, carbohydrates, tannins, coumarins, and alkaloids. RESULTS: The gas chromatography-mass spectrometry analysis showed the presence of 12 and nine chemical compounds in aqueous and chloroform extracts, respectively. C. olitorius decreased serum glucose level and $\alpha$-amylase activity. This effect was more pronounced in the total alcoholic extract and its chloroform fraction than the aqueous one. The extracts also adjusted the lipid profile, reduced liver injury parameters, and caused remarkable improvement and increase number, size, and density of functioning $\beta$-cells.

CONCLUSION: The findings suggest the antihyperglycemic and antioxidant effects of $C$. olitorius besides its beneficia effect on diabetic complications such as hyperlipidemia and liver injury. The presence of some phytochemicals such as theophylline, trans-2, 3-dimethoxycinnamic acid, 7-hydroxy-4-methyl coumarin, apigenin 7-glucoside, and glycitein may contribute to such pharmacological effects.

\section{Introduction}

Type 1 diabetes is a chronic disease that is associated with several long-term complications, including microvascular and macrovascular events such as neuropathy, hyperlipidemia, nephropathy, and retinopathy. Nowadays, the life expectancy of type 1 diabetic patients is still about 12 years less than that of the general population [1]. The burden of longterm care and increased morbidity necessitate more studies to prevent, treat and even achieve a true cure for this complicated disease. In fact, the improvements achieved in insulin delivery systems provided better control of blood glucose; however, there is a continuing demand for newer therapies to cope with the devastating complications that occur alongside [2].

Corchorus olitorius L. belongs to family Tiliaceae and known as "Jute," which is characterized by the presence of high ratios of amino acids; hence, it is an essential source of dietary protein in Egypt and many other countries. Leaves of $C$. olitorius are edible and its ethnic soup is well-known in Egypt under the name of "Molukhyia." The leaves were found to be rich sources of $\omega 3$-octadecatriene fatty acid which is a higher concentration than any other vegetable [3]. The plant has been reported to possess antiinflammatory [4], antibacterial, demulcent, bitter tonic, laxative, carminative, diuretic, useful in chronic cystitis, gonorrhea, and cardiotonic [5], [6]. In previous recent studies, it was shown that the ethanolic seed extract of C. olitorius was effective as an antidiabetic remedy [7] and leaf extract showed antihyperglycemic effects in type 2 diabetic animal model [8].

The present study aims to investigate the antidiabetic effects of $C$. olitorius different leaf extracts using Type 1 diabetic animal model that will be induced by streptozotocin (STZ). A comparative pharmacological study will be performed for the first time between the three extracts; the total alcoholic and its two fractions 
(chloroform and aqueous) to find if the antidiabetic effect of the $C$. olitorius is ascribed to nonpolar (dissolved in chloroform fraction), polar compounds (dissolved in aqueous fraction) alone or due to total extract. Gas chromatography-mass spectrometry (GC-MS) analysis was used also to identify the potential bioactive phytochemicals in those two fractions.

\section{Materials and Methods}

\section{Chemicals}

Gliclazide (standard antidiabetic drug) was purchased from SERVIER subsidiary SERDIA Pharmaceuticals (Canada) in tablet form, grounded using a mortar, and dissolved in distilled water. Chloroform and methanol (purity: 95-99\%) were purchased from El-Gomhouria Co. (Egypt). STZ was purchased from Sigma-Aldrich Chemie $\mathrm{GmbH}$ Co. (Germany).

\section{material \\ Collection and identification of the plant}

C. olitorius leaves that used in the study were supplied by Haraz flour Milling, Cairo, Egypt. C. olitorius leaves were cleaned and stored in a cool and dry place before use. A voucher specimen (Reg. No.: Co, 201380) was deposited in the herbarium of Pharmacognosy Department, Faculty of Pharmacy, Al-Azhar University and it was air-dried and kept in a tightly closed container.

\section{Preliminary phytochemical investigation}

Phytochemical screening was performed using standard procedures based on colorimetric tests [9], [10]. C. olitorius leaves were screened for the presence of carbohydrates, saponins and/or glycosides, alkaloids, anthraquinones, unsaturated sterols, triterpenes, coumarins, tannins, cardiac glycosides, and flavonoids. The phytochemical screening revealed the presence of all the previous phytochemicals except anthraquinones and volatile compounds.

\section{Preparation of extract}

The powdered plant materials $(1.5 \mathrm{~kg})$ were extracted with ethanol (70\%) (1 L/time). The extraction was done by a hot continuous percolation method in the Soxhlet apparatus for $24 \mathrm{~h}$ [11]. The extract was concentrated using a rotary evaporator till dry powder was obtained $(\sim 150 \mathrm{~g})$. The total extract was dissolved at least amount water, extracted by chloroform $(3 \times 1$ $\mathrm{L})$. Using separating funnel, the organic layer and the aqueous layer were separated, and then two fractions were concentrated using a rotary evaporator till dry powder was obtained (40 $\mathrm{g}$ of chloroform and $95 \mathrm{~g}$ of aqueous fractions). The final residues thus obtained were then subjected to GC-MS analysis [12].

\section{GC-MS analysis}

The chloroform and aqueous fractions of C. olitorius leaves were analyzed through GC-MS for the identification of different compounds. The GC-MS analysis was carried out using a GC (Agilent Technologies 7890A) interfaced with a mass selective detector (MSD, Agilent 7 000) equipped with a polar Agilent HP-5ms (5\%-phenyl methyl polysiloxane) capillary column $(30 \mathrm{~m} \times 0.25 \mathrm{~mm}$ i.d. and $0.25 \mu \mathrm{m}$ film thickness). The oven temperature was programmed initially at $40^{\circ} \mathrm{C}$ (for $3 \mathrm{~min}$ ) to $280^{\circ} \mathrm{C}$ final at an increasing rate of $5^{\circ} \mathrm{C} / \mathrm{min}$ (for $5 \mathrm{~min}$ ). The carrier gas was helium with a linear velocity of $1 \mathrm{~mL} / \mathrm{min}$. The electron ionization system with ionization energy of $70 \mathrm{eV}$ was used.

\section{The identification of components}

Interpretation of the mass spectrum of GC-MS was based on using the database of the National Institute Standard and Techniques (NIST Version, 2008), which have more patterns. The relative percentage amount of each component was calculated by comparing its average peak area to the total areas. The spectrum of the unknown compound was compared with the spectrum of the compound stored in the NIST data library (NIST08s), WILEY8, and Adams. The name, molecular weight, molecular formula, and structure of the components of the test material were obtained.

\section{Assessment of antidiabetic activity}

\section{Animals}

Healthy male Wistar rats, weighing 200-220 g, were obtained from the animal house of the National Research Centre. Before initiating the experiments, the rats were allowed to acclimatize for a few days under standard environmental conditions (12 h dark/12 h light cycle; temperature $20-22^{\circ} \mathrm{C}$; relative humidity $40-60 \%$ ). The animals were cared for in accordance with the Guide to the Care and Use of Experimental Animals available from the Canadian Council on Animal Care. The ethical standards of the experiment are also in accordance with the guidelines provided by the CPCSEA and World Medical Association Declaration of Helsinki on Ethical Principles for Medical Research. The animal use was approved and conducted according to regulations of the ethics committee of the National Research Centre which gave its consent in accordance with the National Regulations on Animal Welfare and Institutional Animal Ethical Committee (Approval No: 17-062). 


\section{Induction of diabetes and animal grouping}

Type 1 diabetes mellitus was induced by a single i.p. injection of a freshly prepared solution of STZ ( $52.5 \mathrm{mg} / \mathrm{kg}$ body weight) in $0.1 \mathrm{M}$ citrate buffer ( $\mathrm{pH} 4.3)$ after a fasting period of $24 \mathrm{~h}$ [13]. On the $3^{\text {rd }}$ day of STZ injection, blood was collected from tail veins of rats and glucose level was measured. Rats with a serum glucose level of $180 \mathrm{mg} / \mathrm{dL}$ or greater were considered diabetic and selected in this study. A group of six rats was kept as a negative control group and received $1 \mathrm{~mL}$ saline orally (Group 1). After induction of diabetes, rats were divided into other eight equal groups (six rats per group). Group 2 (positive control) received STZ only, as mentioned above. Group 3 received oral administration of the reference drug (gliclazide, $10 \mathrm{mg} / \mathrm{kg}$ ). Groups 4-9 rats were administered $C$. olitorius at two different oral doses; 50 and $100 \mathrm{mg} / \mathrm{kg}$ as reported in literature [14] as follows: Groups 4 and 5 received STZ and C. olitorius total alcoholic extract at two dose levels: 50 and $100 \mathrm{mg} / \mathrm{kg}$ bw, respectively. Groups 6 and 7 received C. olitorius aqueous extract at 50 and $100 \mathrm{mg} / \mathrm{kg}$ bw, respectively. Groups 8 and 9 received C. olitorius chloroform extract at 50 and $100 \mathrm{mg} / \mathrm{kg}$ bw, respectively.

Treatment with $C$. olitorius extracts was started 3 days after STZ injection and lasted for 14 days. At the end of the experiment, blood samples were drawn from the tail veins of rats [15] for recording fasting serum glucose in each group on days 3 (beginning of diabetes induction) and 17 (last day of the experiment, after treatment) of the study. Serum glucose was measured using glucose kit (Stanbio Laboratory, USA), according to Trinder [16]. Serum samples were obtained by centrifugation at $3000 \mathrm{rpm}$ for $10 \mathrm{~min}$ using the cooling centrifuge (Sigma and Laborzentrifugen, 2 k15, Germany) and used for biochemical measurements.

\section{Biochemical assay}

The collected sera were used for the determination of $\alpha$-amylase, total antioxidant capacity (TAC), total cholesterol, triglycerides level, LDL, HDL, AST, and ALT using specific kits (Chronolab, Spain). The procedures were done according to the manufacturer's instructions. Percent of change of each indicator from positive control (STZ diabetic group) was calculated according to the following formula:

$\%$ change $=[$ (Conc. in STZ group-Conc. in treated group)/Conc. in STZ group] ${ }^{*} 100$

\section{Histopathological examination}

After sacrifice, animal organs (pancreas or liver) were dissected, extracted, and immediately fixed in buffered formalin. Tissues were further dehydrated, embedded into paraffin blocks, and serially sectioned at 4 microns thickness. Paraffin sections were stained with hematoxylin and eosin for routine histopathological study [17].
Further paraffin sections were stained immunohistochemically with insulin mouse Monoclonal Antibody INS05 (2D11-H5)-Thermo-Fisher.

Stained sections were examined using the light microscope OLYMPUS CX41 and photomicrographs were taken using digital camera OLYMPUS DP12.

\section{Statistical analysis}

All studied data were statistically analyzed using GraphPad Software Computer Program; version 6 hypothesis testing methods included one-way analysis of variance (ANOVA) using the Tukey test as post hoc test. Data were represented as mean \pm SEM. $p \leq 0.05$ was considered to be statistically significant.

\section{Results}

\section{GC-MS analysis}

GC-MS chromatogram of the aqueous extract showed 12 peaks indicating the presence of 12 phytochemical compounds, and the chromatogram of the chloroform extract showed nine phytochemical compounds. The mass spectra of identified compounds were matched with those found in NIST/ NBS spectral database given in Tables 1 and 2.

Table 1: Phytochemical compound identified in aqueous extract of leaves of Corchorus olitorius L.

\begin{tabular}{lllll}
\hline RT & Name of the compound & $\begin{array}{l}\text { Molecular } \\
\text { formula }\end{array}$ & $\begin{array}{l}\text { Molecular } \\
\text { weight }\end{array}$ & $\begin{array}{l}\text { Peak } \\
\text { area (\%) }\end{array}$ \\
\hline 3.49 & Levoglucosenone & $\mathrm{C}_{6} \mathrm{H}_{6} \mathrm{O}_{3}$ & 126 & 5.0 \\
3.76 & 6-Acetyl- $\beta$-D-mannose & $\mathrm{C}_{8} \mathrm{H}_{14} \mathrm{O}_{7}$ & 222 & 14.0 \\
9.78 & Ascaridole epoxide & $\mathrm{C}_{10} \mathrm{H}_{16} \mathrm{O}_{3}$ & 184 & 1.8 \\
9.96 & 2-(2-Methyl-propenyl)-cyclohexanone & $\mathrm{C}_{10} \mathrm{H}_{16} \mathrm{O}_{3}$ & 152 & 1.3 \\
10.98 & D-lyxo-D-manno-nononic-1,4-lactone & $\mathrm{C}_{9} \mathrm{H}_{16} \mathrm{O}_{9}$ & 268 & 0.5 \\
11.77 & N-acetyl-D-galactosaminitol & $\mathrm{C}_{8} \mathrm{H}_{17} \mathrm{NO}_{6}$ & 223 & 0.9 \\
13.52 & Digitoxin & $\mathrm{C}_{41} \mathrm{H}_{64} \mathrm{O}_{13}$ & 764 & 4.2 \\
14.07 & 1-Deoxy-1-(methylamino) hexitol & $\mathrm{C}_{7} \mathrm{H}_{17} \mathrm{NO}_{5}$ & 195 & 5.4 \\
15.05 & Theophylline & $\mathrm{C}_{7} \mathrm{H}_{8} \mathrm{~N}_{4} \mathrm{O}_{2}$ & 180 & 7.2 \\
17.58 & Trans-2,3-dimethoxycinnamic acid & $\mathrm{C}_{11} \mathrm{H}_{12} \mathrm{O}_{4}$ & 208 & 2.0 \\
20.08 & Isoelemicin & $\mathrm{C}_{12} \mathrm{H}_{16} \mathrm{O}_{3}$ & 208 & 1.7 \\
21.45 & Nabilone & $\mathrm{C}_{24} \mathrm{H}_{36} \mathrm{O}_{3}$ & 372 & 6.2 \\
\hline
\end{tabular}

The identification of the phytochemical compounds was confirmed based on the peak area, retention time, and molecular formula. The individual fragmentation patterns of necessary compounds were illustrated in Figure 1.

Table 2: Phytochemical compound identified in chloroform extract of leaves of Corchorus olitorius $\mathrm{L}$.

\begin{tabular}{lllll}
\hline RT & Name of the compound & $\begin{array}{l}\text { Molecular } \\
\text { formula }\end{array}$ & $\begin{array}{l}\text { Molecular } \\
\text { weight }\end{array}$ & $\begin{array}{l}\text { Peak area } \\
(\%)\end{array}$ \\
\hline 9.75 & 7-Hydroxy-4-methyl coumarin & $\mathrm{C}_{10} \mathrm{H}_{8} \mathrm{O}_{3}$ & 176 & 0.32 \\
10.19 & 3,4-Dimethoxycinnamic acid & $\mathrm{C}_{11} \mathrm{H}_{12} \mathrm{O}_{4}$ & 208 & 0.34 \\
10.84 & D-saccharic acid 1,4-lactone & $\mathrm{C}_{6} \mathrm{H}_{8} \mathrm{O}_{7} \mathrm{H}_{2} \mathrm{O}$ & 210 & 0.41 \\
12.60 & Camphoric acid & $\mathrm{C}_{10} \mathrm{H}_{16} \mathrm{O}_{4}$ & 200 & 3.80 \\
13.84 & Apigenin 7-glucoside & $\mathrm{C}_{21} \mathrm{H}_{20} \mathrm{O}_{10}$ & 432 & 4.36 \\
13.90 & 3-tocopherol & $\mathrm{C}_{28} \mathrm{H}_{48} \mathrm{O}_{2}$ & 416 & 0.99 \\
15.03 & 3-Oxo-7,8-dihydro- $\alpha$-ionol & $\mathrm{C}_{13} \mathrm{H}_{22} \mathrm{O}_{2}$ & 210 & 11.56 \\
15.46 & 4-Hydroxy-2-methoxybenzaldehyde & $\mathrm{C}_{8} \mathrm{H}_{8} \mathrm{O}_{3}$ & 152 & 30.95 \\
15.58 & Glycitein & $\mathrm{C}_{16} \mathrm{H}_{12} \mathrm{O}_{5}$ & 284 & 1.33 \\
\hline
\end{tabular}




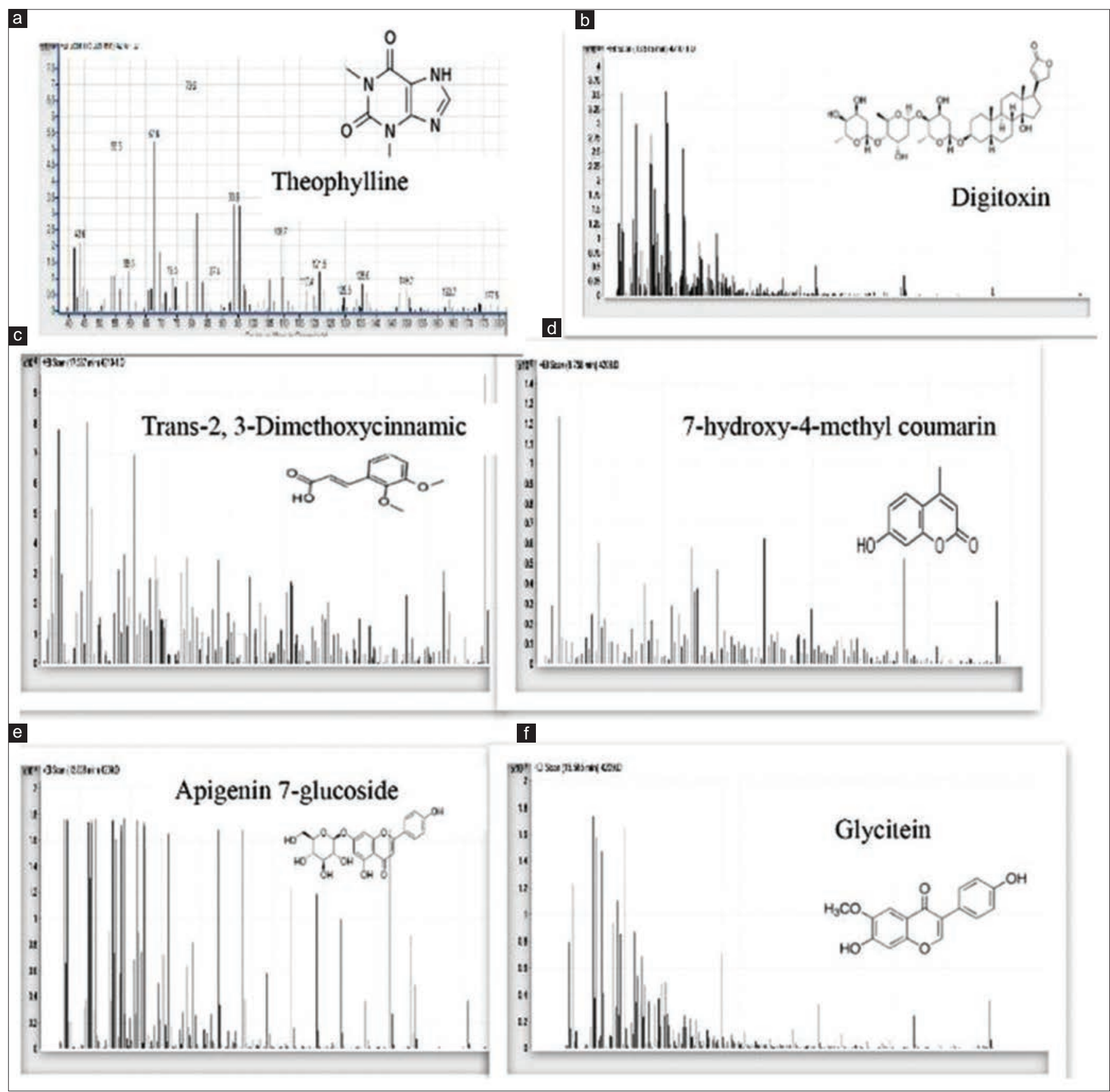

Figure 1: The individual fragmentation pattern of the important compounds in gas chromatography analysis. (a) Theophylline, (b) Trans-2,3dimethoxycinnamic acid, (c) 7-Hydroxy-4-methyl coumarin, (d) Digitoxin, (e) Apigenin 7-glucoside, (f) Glycitein

\section{Biochemical assay}

\section{Effect on fasting glucose level}

As shown in Table 3, initial serum glucose was significantly increased $(p<0.05)$ in all STZ-treated groups as compared to the negative control one (confirming diabetes). At the end of the experiment, glucose level was significantly increased $(p<0.05)$ in the diabetic group exhibiting $24 \%$ increase from the initial value. After $C$. olitorius administration, glucose level was significantly decreased $(p<0.05)$ in gliclazide (standard drug), total alcoholic $C$. olitorius extract (100 mg/kg), aqueous (100 mg/kg), and chloroform C. olitorius fractions (50 and $100 \mathrm{mg} / \mathrm{kg}$ ) by $66 \%$, $65 \%, 38 \%, 66 \%$, and $50 \%$, respectively, compared to STZ-diabetic group. It is worthy to note that total alcoholic and aqueous extracts decreased glucose level in a dose-dependent manner.

\section{Effect on a amylase activity}

Table 3 obviously showed that the activity of $\alpha$ amylase in the STZ-diabetic group was increased significantly ( $p<0.05$ ) compared to the negative control. The activity of $\alpha$ amylase was decreased in animal groups treated with gliclazide, total $C$. olitorius extract $(100 \mathrm{mg} / \mathrm{kg})$, aqueous C. olitorius fraction (100 $\mathrm{mg} / \mathrm{kg}$ ), and chloroform C. olitorius fractions (50 and $100 \mathrm{mg} / \mathrm{kg}$ ) by $12 \%, 9 \%, 9 \%, 12 \%$, and $8 \%$, 
Table 3: Effect of Corchorus olitorius L. on serum glucose, a amylase, and TAC

\begin{tabular}{|c|c|c|c|c|}
\hline Treatment & $\begin{array}{l}\text { Glucose (initial) } \\
\text { (mg/dL) }\end{array}$ & $\begin{array}{l}\text { Glucose (final) } \\
\text { (mg/dL) }\end{array}$ & $\begin{array}{l}\alpha \text {-amylase } \\
\text { activity }(\mathrm{U} / \mathrm{L})\end{array}$ & TAC (mMol/L) \\
\hline $\begin{array}{l}\text { Control negative } \\
\text { (normal) }\end{array}$ & $101.80 \pm 4.70^{\mathrm{a}}$ & $106.0 \pm 3.8^{\mathrm{a}}$ & $1162.0 \pm 6.1^{\mathrm{a}}$ & $2.64 \pm 0.02^{\mathrm{a}}$ \\
\hline $\begin{array}{l}\text { Control positive } \\
\text { (STZ, } 52.5 \mathrm{mg} / \mathrm{kg} \text { ) }\end{array}$ & $424.40 \pm 18.10^{*}$ & $558.4 \pm 26.1^{*}$ & $1284.0 \pm 4.9^{*}$ & $2.33 \pm 0.04^{*}$ \\
\hline $\begin{array}{l}\text { Gliclazide } \\
(10 \mathrm{mg} / \mathrm{kg})\end{array}$ & $410.60 \pm 20.10^{*}$ & $187.5 \pm 10.1^{\mathrm{a}}$ & $1130.0 \pm 8.2^{\mathrm{a}}$ & $2.61 \pm 0.05^{\mathrm{a}}$ \\
\hline $\begin{array}{l}\text { C. olitorius tot alc } \\
\text { ext ( } 50 \mathrm{mg} / \mathrm{kg})\end{array}$ & $428.20 \pm 38.90^{*}$ & $582.7 \pm 35.6^{*}$ & $1269.0 \pm 38.5^{\star^{c}}$ & $2.30 \pm 0.02^{\star^{c}}$ \\
\hline $\begin{array}{l}\text { C. olitorius tot alc } \\
\text { ext (100 mg/kg) }\end{array}$ & $325.30 \pm 24.80^{*}$ & $190.5 \pm 5.4^{\mathrm{a}, \mathrm{b}}$ & $1170.0 \pm 18.6^{\mathrm{a}, \mathrm{b}}$ & $2.60 \pm 0.05^{\mathrm{a}, \mathrm{b}}$ \\
\hline $\begin{array}{l}\text { C. olitorius } \\
\text { aqueous ext } \\
(50 \mathrm{mg} / \mathrm{kg}\end{array}$ & $378.60 \pm 27.20^{*}$ & $490.6 \pm 22.1^{*}$ & $1266.0 \pm 16.2^{*}$ & $2.45 \pm 0.02^{*}$ \\
\hline $\begin{array}{l}\text { C. olitorius } \\
\text { aqueous ext } \\
(100 \mathrm{mg} / \mathrm{kg})\end{array}$ & $366.50 \pm 34.00^{*}$ & $346.7 \pm 27.7^{\star a, d}$ & $1169.0 \pm 11.8^{\text {ad }}$ & $2.35 \pm 0.04^{*}$ \\
\hline $\begin{array}{l}\text { C. olitorius } \\
\text { chloroform ext } \\
(50 \mathrm{mg} / \mathrm{kg})\end{array}$ & $379.10 \pm 37.70^{*}$ & $191.6 \pm 6.2^{\mathrm{a}}$ & $1135.0 \pm 7.6$ & $2.64 \pm 0.03^{\mathrm{a}}$ \\
\hline $\begin{array}{l}\text { C. olitorius } \\
\text { chloroform ext } \\
(100 \mathrm{mg} / \mathrm{kg})\end{array}$ & $332.50 \pm 13.56^{*}$ & $279.2 \pm 22.5^{\star^{a}}$ & $1183.0 \pm 3.2^{\mathrm{a}}$ & $2.65 \pm 0.03^{\mathrm{a}}$ \\
\hline $\begin{array}{l}\text { Each value represent } \\
p<0.05,{ }^{2} \text { Significantly } \\
(50 \mathrm{mg} / \mathrm{kg}) \text {. 'Significa } \\
(50 \mathrm{mg} / \mathrm{kg}) \text {. Statistical } \\
\text { TAC: Total antioxidan }\end{array}$ & $\begin{array}{l}\text { mean } \pm \text { SEM }(n=6 \\
\text { ent from control p } \\
\text { ifferent from tot a } \\
\text { ysis was carried } \\
\text { acity, STZ: Strept }\end{array}$ & $\begin{array}{l}{ }^{*} \text { Significantly diffe } \\
\text { sitive }(\mathrm{STZ}) \text { at } p<0 \\
\text { ext }(100 \mathrm{mg} / \mathrm{kg}) \text {. } \\
\text { t using one-way A } \\
\text { otocin, C. olitorius }\end{array}$ & $\begin{array}{l}\text { om control negative } \\
\text { Significantly differen } \\
\text { icantly different from } \\
\text { test followed by Tu } \\
\text { chorus olitorius. }\end{array}$ & $\begin{array}{l}\text { (saline) at } \\
\text { t from tot alc ext } \\
\text { aqueous ext } \\
\text { key post hoc test. }\end{array}$ \\
\hline
\end{tabular}

respectively, compared to STZ-diabetic group and returned to normal value. The effects of two doses (50 and $100 \mathrm{mg} / \mathrm{kg}$ ) were significantly different in the groups treated with total alcoholic and aqueous extracts. From the data represented in the table, an inhibition in $\alpha$ amylase activity was more pronounced in the group treated with chloroform C. olitorius fraction $(50 \mathrm{mg} / \mathrm{kg})$ and gliclazide.

\section{Effect on TAC}

TAC was significantly decreased $(p<0.05)$ in the positive control group compared to the negative control group. Treatment with gliclazide, total alcoholic C. olitorius extract $(100 \mathrm{mg} / \mathrm{kg})$, and chloroform C. olitorius fractions (50 and $100 \mathrm{mg} / \mathrm{kg}$ ) normalized TAC as shown in Table 3. The groups treated with total alc extract at different doses were significantly different from each other. The TAC increased by $12 \%, 11 \%$, $13 \%$, and $14 \%$ in the previous groups, respectively, compared to the STZ-diabetic group.

\section{Effect on lipid profile}

Lipid profile is presented in Table 4. Cholesterol and triglycerides levels increased significantly $(p<0.05)$ in diabetic groups as compared to the negative control group. Levels of cholesterol and triglycerides decreased significantly $(p<0.05)$ in animals treated with $C$. olitorius total alcoholic extract and its fractions except for triglycerides level in the group treated with the total alcoholic extract $(100 \mathrm{mg} / \mathrm{kg})$ and gliclazide comparing to diabetic group. Levels approached that of the negative control group in animals treated with aqueous and chloroform fractions of $C$. olitorius at both dose levels (except for the total cholesterol value
Table 4: Effect of Corchorus olitorius on serum lipid profile (mg/dL)

\begin{tabular}{|c|c|c|c|c|}
\hline Treatment & Total cholesterol & Triglycerides & LDL & $\mathrm{HDL}$ \\
\hline $\begin{array}{l}\text { Control negative } \\
\text { (normal) }\end{array}$ & $89.17 \pm 1.00^{\mathrm{a}}$ & $48.79 \pm 1.50^{\mathrm{a}}$ & $37.60 \pm 0.30^{\mathrm{a}}$ & $39.80 \pm 3.51^{\mathrm{a}}$ \\
\hline $\begin{array}{l}\text { Control positive } \\
\text { (STZ, } 52.5 \mathrm{mg} / \mathrm{kg})\end{array}$ & $199.20 \pm 12.30^{*}$ & $146.60 \pm 6.30^{*}$ & $44.50 \pm 1.50^{*}$ & $22.89 \pm 1.46^{\star}$ \\
\hline Gliclazide (10 mg/kg) & $110.50 \pm 5.20^{\mathrm{a}}$ & $85.30 \pm 3.20^{\star^{a}}$ & $37.90 \pm 0.60^{\mathrm{a}}$ & $37.10 \pm 0.72^{\mathrm{a}}$ \\
\hline $\begin{array}{l}\text { C. olitorius tot alc ext } \\
(50 \mathrm{mg} / \mathrm{kg})\end{array}$ & $132.70 \pm 2.60^{\star a}$ & $65.20 \pm 4.80^{\mathrm{a}}$ & $38.10 \pm 1.90^{\mathrm{a}}$ & $50.78 \pm 3.18^{\mathrm{a}}$ \\
\hline $\begin{array}{l}\text { C. olitorius tot alc ext } \\
(100 \mathrm{mg} / \mathrm{kg})\end{array}$ & $129.00 \pm 1.30^{\star a}$ & $73.67 \pm 5.10^{*}$ & $37.80 \pm 0.60^{\mathrm{a}}$ & $47.09 \pm 4.34^{\mathrm{a}}$ \\
\hline $\begin{array}{l}\text { C. olitorius aqueous } \\
\text { ext }(50 \mathrm{mg} / \mathrm{kg})\end{array}$ & $114.90 \pm 5.40^{\star a}$ & $60.64 \pm 4.20^{\mathrm{a}}$ & $41.60 \pm 1.10$ & $58.75 \pm 4.15^{\star^{a}}$ \\
\hline $\begin{array}{l}\text { C. olitorius aqueous } \\
\text { ext ( } 100 \mathrm{mg} / \mathrm{kg})\end{array}$ & $71.33 \pm 2.30^{\mathrm{a}, \mathrm{d}}$ & $55.87 \pm 3.10^{\mathrm{a}, \mathrm{d}}$ & $0 \pm 1.60^{\mathrm{a}}$ & $46.42 \pm 2.23^{\mathrm{a}}$ \\
\hline $\begin{array}{l}\text { C. olitorius chloroform } \\
\text { ext }(50 \mathrm{mg} / \mathrm{kg})\end{array}$ & $108.00 \pm 6.50^{\mathrm{a}}$ & $66.50 \pm 1.70^{\mathrm{a}}$ & $35.20 \pm 1.00^{\mathrm{a}}$ & $52.25 \pm 1.61^{\mathrm{a}}$ \\
\hline $\begin{array}{l}\text { C. olitorius chloroform } \\
\text { ext }(100 \mathrm{mg} / \mathrm{kg})\end{array}$ & $100.30 \pm 2.80^{\mathrm{a}}$ & $57.37 \pm 5.30^{\mathrm{a}}$ & $35.40 \pm 1.00^{\mathrm{a}}$ & $50.98 \pm 2.96^{\mathrm{a}}$ \\
\hline $\begin{array}{l}\text { Each value represents the } \\
\mathrm{p}<0.05 \text {, a'Significantly diffe } \\
(50 \mathrm{mg} / \mathrm{kg}) \text {. 'Significantly }\end{array}$ & ean \pm SEM $(n=6)$. & ificantly differ & 2 rentro & $\begin{array}{l}\text { (saline) at } \\
\text { from tot alc ext } \\
\text { aqueous ext }\end{array}$ \\
\hline
\end{tabular}

in the group treated with aqueous extract; $50 \mathrm{mg} / \mathrm{kg}$ ) which exerted $42 \%, 64 \%, 46 \%$, and $50 \%$ decrease in total cholesterol level and $59 \%, 62 \%, 55 \%$, and $61 \%$ decrease in triglycerides level, respectively, compared to STZ-diabetic group. Whereas, gliclazide treatment decreased cholesterol and triglycerides level by $44 \%$ and $42 \%$, respectively, compared to the STZ-diabetic group. For cholesterol, aqueous extract $(50 \mathrm{mg} / \mathrm{kg})$ treatment showed a significant difference from the group treated with the same extract at $100 \mathrm{mg} / \mathrm{kg}$. HDL-cholesterol level significantly $(p<0.05)$ decreased in the STZtreated group as compared to the negative control. HDLcholesterol showed a remarkable increase in all extract treatment groups $(p<0.05)$ compared to the diabetic group and its level was higher than the normal value. Whereas, LDL-cholesterol level increased significantly $(p<0.05)$ in the diabetic group compared to the negative control group. After $C$. olitorius administration, LDLcholesterol levels were decreased in all treated groups $(p<0.05)$ compared to the diabetic group except for the aqueous extract $(50 \mathrm{mg} / \mathrm{kg})$ treated group. The highest decrease was observed in the chloroform fraction treated groups (50 and $100 \mathrm{mg} / \mathrm{kg}$ ) which were $21 \%$ and $20 \%$ when compared to the STZ-diabetic group. There was no significant difference in LDL-cholesterol levels in all treatment groups as compared to the negative control group.

\section{Effect on liver enzymes}

As illustrated in Table 5, ALT and AST revealed a significant increase $(p<0.05)$ in the positive control group compared to the negative control. Administration of the different extracts of $C$. olitorius showed a significant decrease $(p<0.05)$ in ALT and AST activities compared to the positive control group. ALT activity was decreased by $23 \%, 35 \%, 40 \%, 52 \%, 40 \%$, and $50 \%$ after administration of total alcoholic extract (50 and $100 \mathrm{mg} / \mathrm{kg}$ ), aqueous extract (50 and $100 \mathrm{mg} / \mathrm{kg}$ ), and chloroform fraction (50 and $100 \mathrm{mg} / \mathrm{kg}$ ), respectively. The effect on AST activity was more pronounced in the 
Table 5: Effect of Corchorus olitorius L. on serum liver enzymes (U/L)

\begin{tabular}{|c|c|c|}
\hline Treatment & ALT & AST \\
\hline Control negative (normal) & $114.5 \pm 5.3^{\mathrm{a}}$ & $155.5 \pm 1.9^{\mathrm{a}}$ \\
\hline Control positive (STZ, $52.5 \mathrm{mg} / \mathrm{kg}$ ) & $221.2 \pm 16.3^{*}$ & $253.5 \pm 12.3^{*}$ \\
\hline Gliclazide (10 mg/kg) & $175.3 \pm 6.2^{\star a}$ & $220.1 \pm 19.1^{* a}$ \\
\hline C. olitorius Tot alc ext (50 mg/kg) & $169.7 \pm 7.4^{* a}$ & $182.5 \pm 2.4^{\mathrm{a}}$ \\
\hline C. olitorius Tot alc ext ( $100 \mathrm{mg} / \mathrm{kg})$ & $143.3 \pm 7.6^{\mathrm{a}}$ & $212.8 \pm 2.6^{\star a}$ \\
\hline C. olitorius aqueous ext (50 mg/kg) & $135.2 \pm 9.6^{\mathrm{a}}$ & $213.1 \pm 8.6^{\star^{a}}$ \\
\hline C. olitorius aqueous ext (100 mg/kg) & $105.2 \pm 3.2^{\mathrm{a}}$ & $210.1 \pm 6.4^{* a}$ \\
\hline C. olitorius Chloroform ext (50 mg/kg) & $133.3 \pm 3.2^{\mathrm{a}}$ & $217.6 \pm 7.0^{* a}$ \\
\hline C. olitorius Chloroform ext (100 mg/kg) & $109.3 \pm 5.4^{\mathrm{a}}$ & $218.5 \pm 4.4^{\star a}$ \\
\hline
\end{tabular}

group treated with the total alcoholic extract $(50 \mathrm{mg} / \mathrm{kg}$ ). The improvement in biochemical parameters achieved by $C$. olitorius extracts was comparable to the standard antidiabetic drug gliclazide.

\section{Histopathological findings}

The histologic appearance of the pancreatic tissues of the negative control rats showed that normal islets of Langerhans are surrounded by ordinary pancreatic acini. Islets were regular with well-defined boundaries. Cells within islets showed oval to rounded nuclei, disposed in organized architecture. Surrounding pancreatic acini were lined by pyramidal cells showing ample apical cytoplasm and rounded, bland, basophilic basoluminal nuclei (Figure 2a). The pancreas of diabetic untreated rats showed disruption of the architecture and microstructure within the islets of Langerhans. Prominent vacuolar degeneration was observed with focal necrosis. Karyolysis was seen with foci of pyknosis and scattered eosinophilic bodies. Changes were most prominent at the center of the islets. Islets also showed irregularity in their shape and appeared small and shrunken (Figure 2b). Scattered islets showed dense inflammatory cellular infiltrate (insulitis). Outside the islets of Langerhans, the pancreatic ductal and acinar epithelium appeared normal. Treatment with reference drug (gliclazide) showed improvement in size, cellularity, and architectural arrangement within islets, approximating negative control (Figure 2c). Treatment with total alcoholic extract $(100 \mathrm{mg} / \mathrm{kg})$ caused remarkable improvement in the pancreas (Figure 2e);

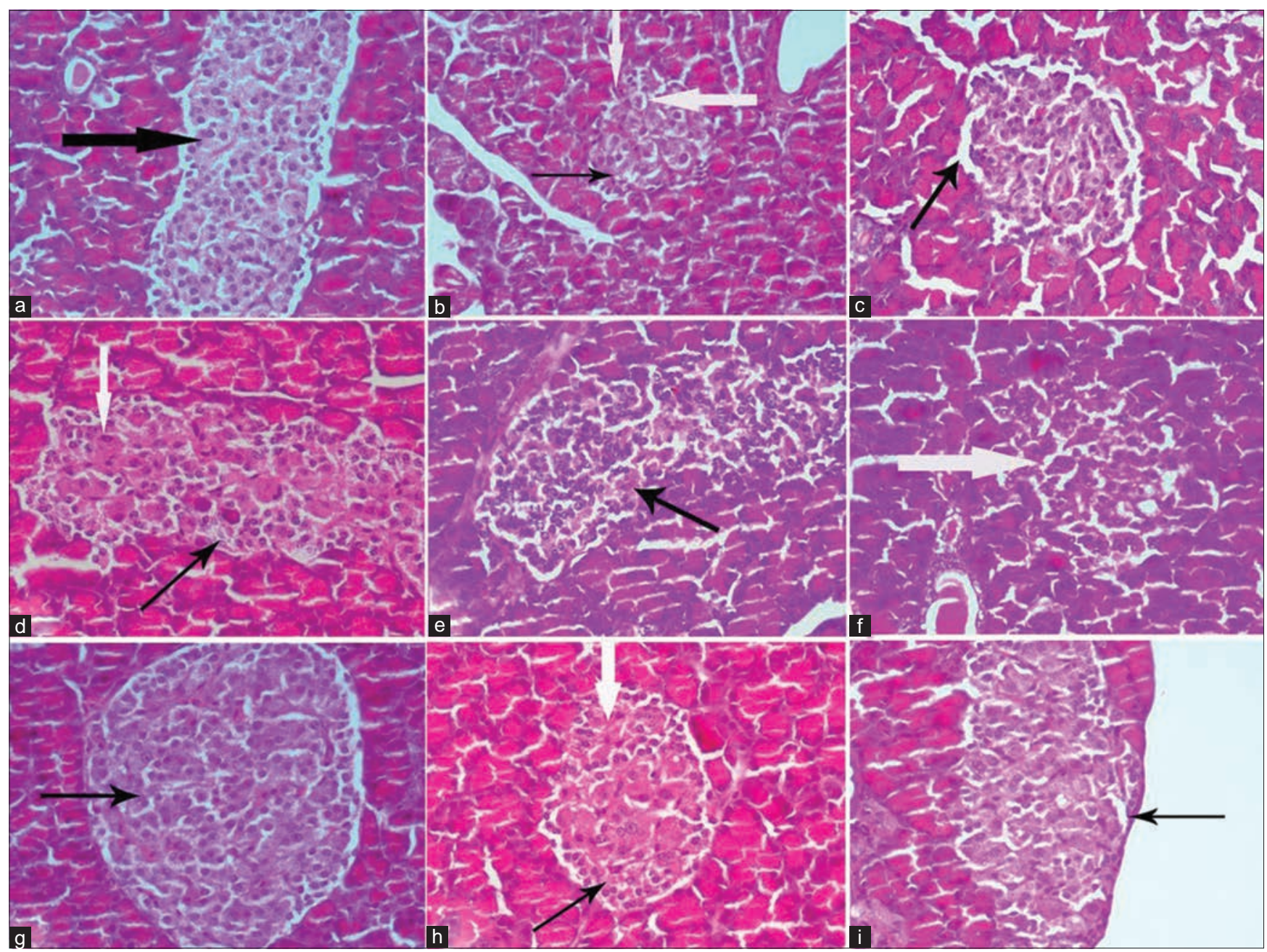

Figure 2: A photomicrograph of pancreatic tissue using hematoxylin and eosin ( $H$ and E): (a) -ve control: Large islet of Langerhans (arrow). (b) +ve control: Shrunken, small islet (arrow), degenerated cells (white). (c) Gliclazide improved islet size (arrow) and cellularity. (d) Total alc (50 mg): Vacuolated, pyknotic cells, and eosinophilic bodies (white). (e) Total alc (100 mg): Improved islet (arrow). (f) Aq. ext (50 mg): Small islet and residual degenerated cells (arrow). (g) Aq. ext (100 mg): Improved islet size and cellularity (arrow). (h) Chloroform (50 mg): Residual microvesicular degeneration (black) and scattered hyperchromatic nuclei (white) (i) Chloroform (100 mg): Improved islet (arrow) (H and E, ×400) 
in the form of increase and restoration of number, size, as well as increase within the density of cells inside the islets. Vacuolar degeneration was diminished and necrosis was not seen. Inflammation also decreased. Improvement was most marked using total alcoholic extract, high dose (Figure 2e), and chloroform extract, high dose, approximating normal (Figure 2i), then followed by total alcoholic extract, low dose (Figure 2d). Improvement was less in the case of aqueous, high dose (Figure $2 \mathrm{~g}$ ). No improvement could be noticed on treatment with each of chloroform extract; low dose (Figure 2h) and aqueous; low dose (Figure 2f).

As shown in Figure 3, the liver tissue of the control rat showed preserved architecture. Ordinary, polyhedral hepatocytes were seen with ample eosinophilic cytoplasm and central, rounded vesicular, bland nuclei were seen. Hepatocytes were seen disposed in cords, one cell thick each, radiating from a central vein, and separated by sinusoids (Figure 3a). Liver tissue of positive control rats showed marked dilatation and congestion of central veins. Arteries showed thick walls. Hepatocytes showed hydropic and microvesicular degeneration (Figure 3b). Aggregates of inflammatory cells were seen, especially at the periphery of dilated vessels. Congestion was seen within sinusoids as well. Pyknotic and hyperchromatic nuclei were noticed within scattered hepatocytes. Liver tissue of diabetic rat treated with reference drug (gliclazide) showed remarkable improvement; picture approximating negative control (Figure 3c).
Liver tissue of diabetic rat treated with total alcoholic extract; high dose showed considerable improvement, still mild congestion was seen within the central vein and sinusoids (Figure $3 \mathrm{e}$ ). The liver tissue of diabetic rats treated with chloroform extract; high dose showed neither congestion nor dilatation of central vein and sinusoids; however, scattered hepatocytes showed hyperchromatic nuclei with minimal residual microvesicular degeneration (Figure 3i).

\section{Immunohistochemical findings}

Islets of Langerhans of diabetic rats showed a marked reduction in number, size, and decreased density of functioning $\beta$-cells as demonstrated by an anti-insulin monoclonal antibody (Figure 4b) as compared to normal islets (Figure 4a). However, diabetic rats treated with $\mathrm{C}$. olitorius chloroform extract high dose showed prominent improvement in $\beta$-cells number, size, and density in the islets of Langerhans (Figure 4i). It was better than other extracts (Figure 4d, e, $f, g, h$ ) and gliclazide (Figure 4c).

\section{Discussion}

This study investigates the antidiabetic effects of one of the most popular plants cultivated in Egypt,

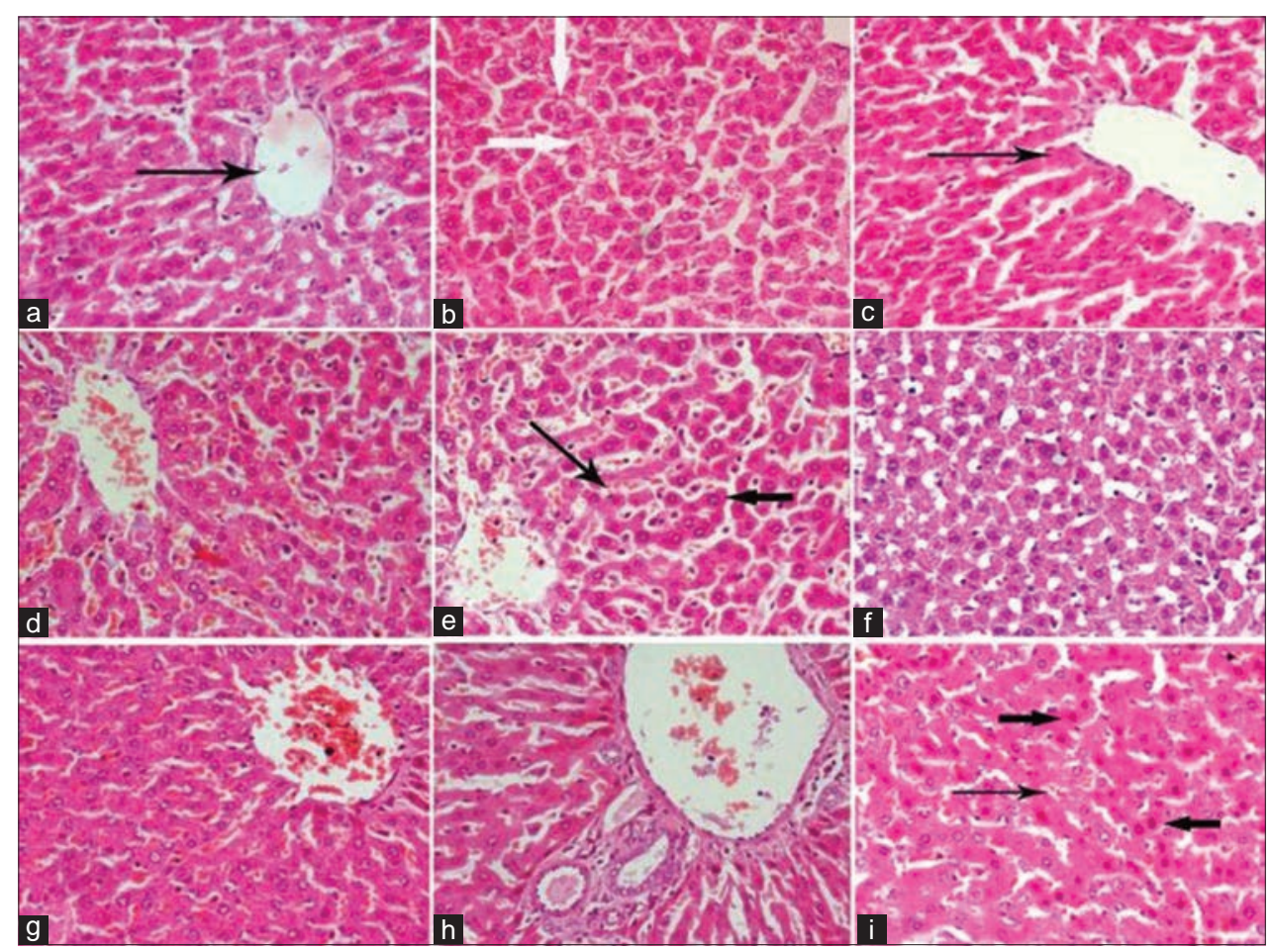

Figure 3: A photomicrograph of liver tissue using hematoxylin and eosin ( $H$ and E). (a) -ve control: Preserved architecture. (b) +ve control: Hydropic degeneration (arrow). (c) Gliclazide: Preserved architecture (arrow). (d) Total alc (50 mg): Mildly congested central vein, scattered inflammatory cells. (e) Total alc (100 mg): Mildly congested central vein (thin arrow). (f) Aq. ext. (50 mg): Normal hepatocyte. (g) Aq. Ext. (100 mg): Mild congested central vein. (h) Chloroform (50 mg): Mild congestion of dilated central vein, proliferating bile ducts, and normal hepatocytes. (i) Chloroform (100 mg): Mildly congested blood sinusoids (thin arrow) and pyknotic hepatocytes (thick arrow) (H and E, ×400) 


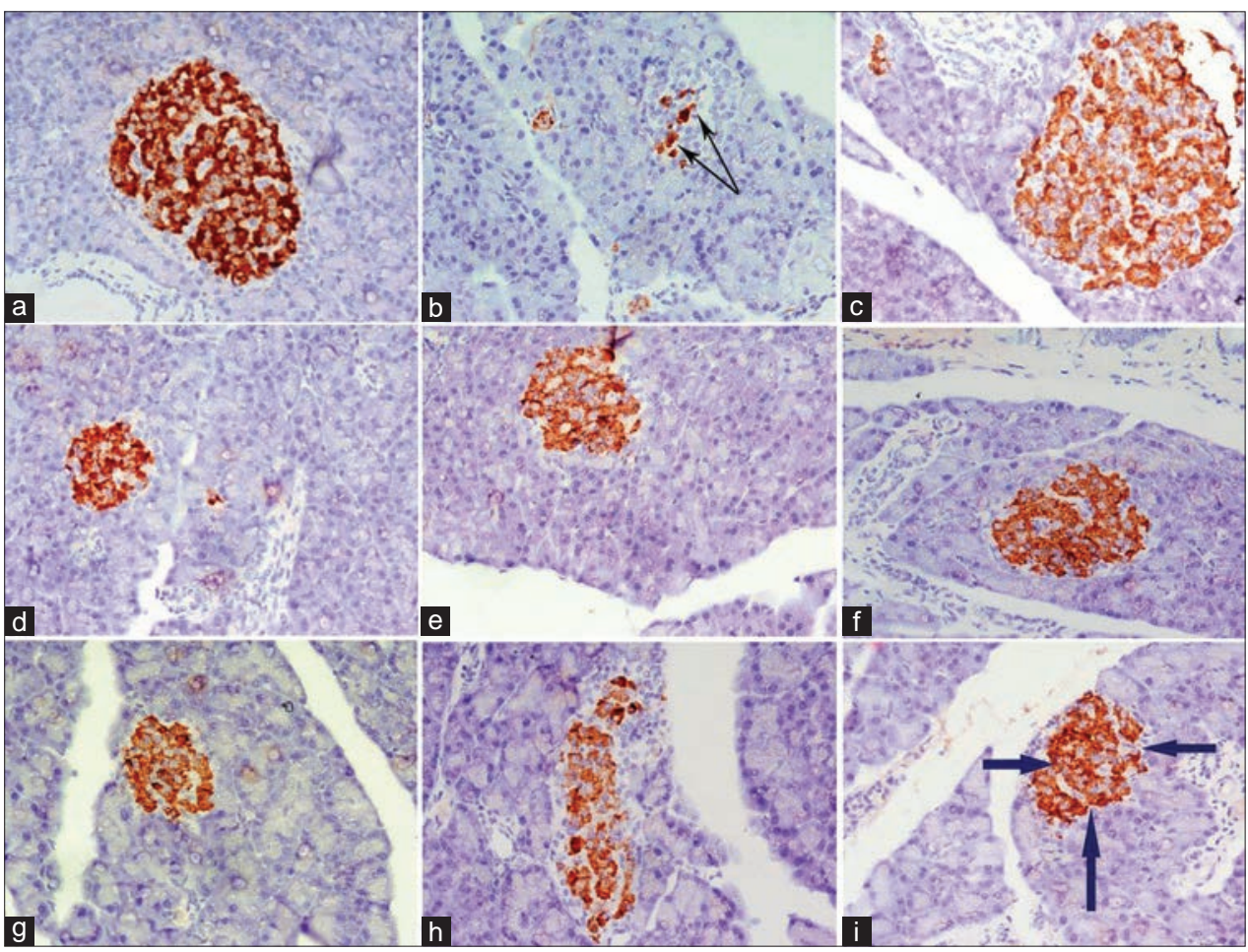

Figure 4: Immunohistochemical detection of insulin in pancreatic tissue: (a) -ve control rat: Large islets and plenty of b-cells with strong intensity and insulin antibody. (b) +ve control: Marked reduction in number, size, and density of $\beta$-cells (black arrow) (c) Gliclazide: Marked improvement of $\beta$-cells. (d) Total alc (50 mg): markedly improved $\beta$-cells. (e) Total alc (100 mg): Improved $\beta$-cells. (f) Aq. ext. (50 mg): Markedly improved of $\beta$-cells. (g) Aq. Ext. (100 mg): Increased $\beta$-cells. (h) Chloroform (50 mg): Markedly improved $\beta$-cells. (i) Chloroform (100 mg): Prominently improved $\beta$-cells number, size, and density (white arrows) (immunoperoxidase $-\times 400$ )

C. olitorius. The individual fragmentation pattern of C. olitorius aqueous and chloroform extracts showed the presence of components from different chemical classes. These phytochemicals were reported to have pharmacological activities with a potential antidiabetic effect such as cinnamic acid and its derivatives, coumarins, apigenin, and glycitein. In a recent reported study, cinnamic acid and its derivatives were found to be associated with protective effects against diabetes and its complications [18]. Similarly, coumarins were found to possess antidiabetic effects [19]. Apigenin is a member of flavones family and showed a hypoglycemic effect in STZ-induced diabetic rats through enhancing GLUT4 translocation and improving the pancreatic architecture, suggesting glucose lowering potential of this flavone as well as $\beta$-cell preserving efficacy [20]. Glycitein is a naturally isoflavone with multiple health benefits attributed to different biological functions. It has been demonstrated that glycitein has an antihyperglycemic effect [21], [22]. Theophylline is a potent bronchodilator that acts as an adenosine receptor antagonist. Adenosine was found to be linked to glucose homeostasis. Adenosine 1 receptor antagonism improved glucose tolerance in Zucker rats through enhancing glucose uptake in skeletal muscle [23]. Derivatives of theophylline were accordingly synthesized and showed a hypoglycemic effect [24].

STZ is a commonly used agent in the induction of diabetes in experimental animals [25]. When used ata large dose (50-75 mg/kg b.w.), STZ produces the destruction of insulin-secreting $\beta$-cells through the generation of free radicals with methylation of DNA. Structural and biochemical alterations developed in this model resemble the consequences of Type1 diabetes mellitus [26]. In the present study, upon the treatment of diabetic rats with the three extracts of $C$. olitorius, serum glucose level was successfully decreased. Histopathological investigation revealed that $C$. olitorius treatment caused remarkable improvement in the pancreatic tissue as reflected by an increased number, size and density of functioning $\beta$-cells. Taken together, it may be concluded that this plant act as an antihyperglycemic agent through stimulation of $\beta$ cells regeneration or functionality. In previous studies, it was shown that the ethanolic seed extract of $C$. olitorius was effective as an antidiabetic remedy [7] and leaf extract showed antihyperglycemic effects in type 2 diabetic animal model [8].

Alpha-amylase is an enzyme involved in carbohydrates digestion. It enhances the hydrolysis of glycosidic linkage in some oligosaccharides and starch. It breaks down complex polysaccharides into oligo- and disaccharides which are further hydrolyzed into monosaccharides by $\alpha$-glucosidase enzyme. These simpler forms can be then readily absorbed into the portal vein and increase serum glucose levels [27]. The activity of the $\alpha$-amylase enzyme increased in the present study by injection of STZ and inhibited by the administration of $C$. olitorius extracts. Inhibition of $\alpha$-amylase keeps carbohydrate digestion and monosaccharide absorption controlled. Their digestion 
is delayed and, accordingly, postprandial hyperglycemia is alleviated. Therefore, amylase inhibitors are of potential therapeutic importance in the treatment of diabetes [28]. Hence, the antihyperglycemic capability of $C$. olitorius can be explained, in part, by regulating carbohydrate kinetics in vivo through inhibition of the $\alpha$-amylase degrading enzyme. This agrees with previous studies that reported the effect of Jute leaves on $\alpha$-amylase but in type 2 diabetes [8]. In coincidence with current histopathological findings, the antihyperglycemic effect was more pronounced in groups treated with chloroform extract than that of aqueous fraction, suggesting that it contains more active phytochemicals against diabetes.

Treatment with C. olitorius showed antioxidant potential, as evidenced by increased TAC. Oxidative stress is one of the main mechanisms that mediate the deleterious effects of diabetes and eventually aggravates diabetic complications. Reactive hydrogen peroxide radicals are formed due to glucose oxidation and disputation with subsequent generation of superoxide anion radicals [29]. Thus, the ability of C. olitorius to restore the altered antioxidant status reveals its free radical scavenging potential. The presence of high contents of flavonoids, saponins, carbohydrates, tannins, and triterpenes further explains the antioxidant effect of the extracts. These phytochemicals act as reducing agents because of their strong redox properties, hydrogen donating, and singlet oxygen quenching activities [30]. It can be deduced that the antioxidant property of $C$. olitorius extract mediates, in part, its antihyperglycemic activity and consequently prevention of diabetic complications. The antioxidant effect was noticed in both the total alcoholic and its chloroform fraction.

Hyperlipidemia is one of the important complications of diabetes and plays a major role in disease prognosis. At normal conditions, insulin prevents the degradation of triglycerides and mobilization of fatty acids from fat stores. However, insulin shortage enhances lipoprotein lipase inactivation which stimulates the assembling of free fatty acids into phospholipids and cholesterol, resulting in raising serum lipids. Treatment with compounds with lipoprotein lipase enhancing effect could suppress elevated serum glucose. The proposed mechanism was controlling lipid metabolism and improving insulin resistance [31]. In parallel, the present lipid profile testing showed an elevation in serum levels of total cholesterol, triglycerides, and LDL-C, whereas HDL-C decreased in STZ-diabetic rats [8]. Treatment with $C$. olitorius extracts not only improved serum phospholipids abnormalities but also normalized their values. The aqueous and chloroform fraction were equally effective against hyperlipidemia. The presence of flavonoids has shown to be associated with decreasing the risk of atherosclerosis due to their ability to lower cholesterol and triglycerides levels and prevention of LDL oxidation [32].
In the present study, the significant increase in serum ALT and AST levels that were observed in STZ-induced diabetic rats represents liver damage compared to negative control rats. Liver necrosis in STZ-induced diabetic rats leads to increased plasma activities of transaminases due to leakage of these enzymes from liver cytosol into the bloodstream [33]. Oral administration of $C$. olitorius showed a protective effect on liver tissue by reducing the elevated levels of ALT and AST. This is in parallel with a recent investigation which showed the hepatoprotective effect of $C$. olitorius and suggested the ability of the plant to maintain the integrity of the hepatocellular membrane [34].

\section{Conclusion}

The present study explores that suppression of $\alpha$-amylase and antioxidant activity is two proposed mechanisms that could mediate the antihyperglycemic effect of $C$. olitorius leaves. This effect varied with the different extracts of $C$. olitorius. The chloroform fraction exerted its antidiabetic activity in a dosedependent manner and was superior in these effects to the aqueous one, indicating the higher efficacy of the nonpolar constituents.

C. olitorius total alcoholic extract (at a dose of $100 \mathrm{mg} / \mathrm{kg}$ ) and it is aqueous (at a dose of $100 \mathrm{mg} / \mathrm{kg}$ ), and chloroform fractions (at both dose levels; 50 and $100 \mathrm{mg} / \mathrm{kg}$ ) also protected against diabetic complications such as hyperlipidemia and determinant effects on the liver tissue. These antidiabetic effects can be ascribed to the presence of some bioactive phytochemical constituents such as theophylline, trans-2, 3-dimethoxycinnamic acid, 7-hydroxy-4-methyl coumarin, apigenin 7-glucoside, and glycitein. The results support the traditional use of this edible plant with the additive effect as an antidiabetic remedy.

\section{References}

1. Huo L, Harding JL, Peeters A. Life expectancy of Type 1 diabetic patients during 1997-2010: A national Australian registry-based cohort study. Diabetologia. 2016;59(6):1177-85. https://doi. org/10.1007/s00125-015-3857-4

PMid:26796634

2. Copenhaver M, Hoffman RP. Type 1 diabetes: Where are we in 2017? Transl Pediatr. 2017;6(4):359-64. https://doi. org/10.21037/tp.2017.09.09

PMid:29184816

3. Mahmoud AS, Thao N, Mario A. Corchorus olitorius Linn: A rich source of $\Omega 3$-fatty acids. Pharm Anal Acta. 2016;7(6):486. https://doi.org/10.4172/2153-2435.1000486

PMid:27722021 
4. Honoré TI, Bernard AK, Gilles KD, Koffi G. Evaluation of the anti-inflammatory activity of aqueous extracts from Corchorus olitorius (Malvaceae). Pharm Innov Int J. 2018;7(4):800-2.

5. Mondal TK, Sohel D, Hassan K, Laso D. Phytochemical and antimicrobial investigations of different fractions of the methanolic extract of Corchorus capsularis leaves. Afr J Pharm Pharmacol. 2017;11(17):209-16. https://doi.org/10.5897/ ajpp2017.4747

6. Guvan K, Yucel E, Gentintas F. Antimicrobial activities of fruits of Crataegus and Pyrus species. Pharm Biol. 2006;4(2):79-83.

7. Egua MO, Etuk EU, Bello S, Hassan S. Anti diabetic activity of ethanolic seed extract of Corchorus olitorius. Int J Sci. 2013;12(1):8-21.

8. Saliu JA, Oboh G, Schetinger MR, Stefanello N, Rocha JB. Antidiabetic potentials of Jute leaf (Corchorus olitorius) on Type-2 diabetic rats. J Emerg Trends Eng Appl Sci. 2015;6(7):223-30.

9. Sofowora A. Medicinal Plants and Traditional Medicine in Africa. Ibadan: Spectrum Books; 1993. p. 150.

10. Trease GE, Evans WC. Pharmacognosy. $13^{\text {th }}$ ed. London: Bailliere Tindall; 1989. p. 176-80.

11. Harborne JB. Phytochemical Methods. New York: Chapman \& Hall; 1984. p. 4-5.

12. Kalimuthu K, Prabakaran R. Preliminary phytochemical screening and GC-MS analysis of methanol extract of Ceropegia pusilla. Int J Res Appl Nat Soc Sci. 2013;1(3):49-58.

13. Barrière DA, Rieusset $J$, Chanteranne $D$, Busserolles $J$ Chauvin MA, Chapuis L, et al. Paclitaxel therapy potentiates cold hyperalgesia in streptozotocin-induced diabetic rats through enhanced mitochondrial reactive oxygen species production and TRPA1 sensitization. Pain. 2012;153(3):553-61. https://doi. org/10.1016/j.pain.2011.11.019

PMid:22177224

14. Das AK, Bag S, Sahu R, Dua TK, Sinha MK, Gangopadhyay M. Protective effect of Corchorus olitorius leaves on sodium arsenite-induced toxicity in experimental rats. Food Chem Toxicol. 2010;48(1):326-35. https://doi.org/10.1016/j. fct.2009.10.020

PMid:19852998

15. Brown C. Blood collection from the tail of a rat. Lab Anim. 2006;35(8):24-5.

16. Trinder P. Determination of blood glucose using an oxidaseperoxidase system with a non-carcinogenic chromogen. J Clin Pathol. 1969;22(2):158-61. https://doi.org/10.1136/jcp.22.2.158 PMid:5776547

17. Drury RA, Wallington EA, Cancerson R. Carleton's Histology Technique. $4^{\text {th }}$ ed. Oxford, London, New York: University Press; 1976.

18. Adisakwattana S. Cinnamic acid and its derivatives: Mechansims for prevention and management of diabetes and its complication. Nutrients. 2017;9(2):163. https://doi.org/10.3390/nu9020163 PMid:28230764

19. Verma A, Dewangan P, Kesharwani D, Kela SP. Hypoglycemic and hypolipidemic activity of scopoletin (coumarin derivative) in streptozotocin induced diabetic rats. Int J Pharm Sci Rev Res. 2013;22(1):79-83.

20. Hassain CM, Ghosh MK, Satapathy BS, Dey NS, Mukherjee B. Apigenin causes biochemical modulation, GLUT4 and CD38 alterations to improve diabetes and to protect damages of some vital organs in experimental diabetes. Am J Pharmacol Toxicol. 2014;9(1):39-52. https://doi.org/10.3844/ajptsp.2014.39.52

21. Gilbert ER, Liu DD. Anti-diabetic functions of soy isoflavone genistein; mechanism underlying effect on pancreatic $\beta$-cell function. Food Funct. 2013;4(2):200-12. https://doi.org/10.1039/ c2fo30199g

PMid:23160185
22. Zang $\mathrm{Y}$, Igarashi $\mathrm{K}, \mathrm{Yu} \mathrm{C}$. Anti-obese and anti-diabetic effects of a mixture of daidzin and glycitin on C57BL/6J mice fed with a high-fat diet. Biosci Biotechnol Biochem. 2015;79(1):117-23. https://doi.org/10.1080/09168451.2014.955453 PMid:25209298

23. Crist $\mathrm{GH}, \mathrm{Xu} \mathrm{B}$, Lanoue $\mathrm{KF}$, Lang $\mathrm{CH}$. Tissue-specific effects of in vivo adenosine receptor blockage on glucose uptake in zucker rats. FASEB J. 1998;12(13):1301-8. https://doi.org/10.1096/ fasebj.12.13.1301

PMid:9761773

24. Alafeefy AM, Alqasoumi SI, Hamid SG, El-Tahir KE, Mohamed M, Zain ME. Synthesis and hypoglycemic activity of some new theophylline derivatives. J Enzyme Inhib Med Chem. 2014;29(3):443-8. https://doi.org/10.3109/14756366.2013.795957 PMid:23701264

25. Mohan Y, Jesuthankaraj GN, Thangavelu NR. Antidiabetic and antioxidant properties of triticumaestivum in streptozotocin induced diabetic rats. Adv Pharmacol Sci. 2013;2013:716073. https://doi.org/10.1155/2013/716073

PMid:24416041

26. Eleazu CO, Eleazu KC, Chukwuma S, Essien UN. Review of the mechanism of celldeath resulting from streptozotocin challenge in experimental animals, its practical use and potentialrisk to humans. J Diabetes Metab Disord. 2013;12(1):60. https://doi. org/10.1186/2251-6581-12-60

PMid:24364898

27. Prabhakar VK, Jaidka A, Singh R. In vitro study on aamylase inhibitory activity and phytochemical screening of few Indian medicinal plant having anti-diabetic properties. Int J Sci Res Public. 2013;3(8):1-6.

28. Agarwal P, Ritika G. Alpha-amylase inhibition can treat diabetes mellitus. Res Rev J Med Health Sci. 2016;5(4):1-8

29. Phaniendra A, Jestadi DB, Periyasamy L. Free radicals: Properties, sources, targets, and their implication in various diseases. Indian J Clin Biochem. 2015;30(1):11-26. https://doi. org/10.1007/s12291-014-0446-0 PMid:25646037

30. Gülcin I, Elmastas M, Aboul-Enein HY. Determination of antioxidant and radical scavenging activity of basil (Ocimum basilicum L. family Lamiaceae) assayed by different methodologies. Phytother Res. 2007;21(4):354-61. https://doi. org/10.1002/ptr.2069

PMid:17221941

31. Walton RG, Zhu B, Unal R, Spencer M, Sunkara M, Morris AJ, et al. Increasing adipocyte lipoprotein lipase improves glucose metabolism in high fat diet-induced obesity. J Biol Chem. 2015;290(18):11547-6. https://doi.org/10.1074/jbc. $\mathrm{m} 114.628487$ PMid:25784555

32. Siasos G, Tousoulis D, Tsigkou V, Kokkou E, Oikonomou E, Vavuranakis M, etal. Flavonoids in atherosclerosis:An overview of their mechanisms of action. Curr Med Chem. 2013;20(21):264160. https://doi.org/10.2174/0929867311320210003 PMid:23627935

33. Afrin R, Arumugam S, Soetikno V, Thandavarayan RA, Pitchaimani V, Karuppagounder V, et al. Curcumin ameliorates streptozotocin-induced liver damage through modulation of endoplasmic reticulum stress-mediated apoptosis in diabetic rats. Free Radic Res. 2015;49(3):279-89. https://doi.org/10.31 09/10715762.2014.999674

PMid:25536420

34. Omeje K, Omeje H, Odiba A, Anunobi O, Ukegbu C. Liver enzymes and lipid activities in response to Corchorus olitorius leaf extract. Int J Curr Res Biosci Plant Biol. 2016;3(6):45-9. https://doi.org/10.20546/ijcrbp.2016.306.007 